\title{
Boll characteristics and yield of cotton in relation to the canopy microclimate under varying plant densities in an arid area
}

\author{
Na Zhang ${ }^{\text {Equal first author, } 1}$, Liwen Tian Equal first author, 2 , Lu Feng ${ }^{3}$, Wenxiu Xu ${ }^{\text {Corresp., } 1}{ }^{2}$ Yabing $\mathbf{L i}^{\text {Corresp., } 3}$, Fangfang Xing ${ }^{3}$, \\ Zhengyi Fan ${ }^{3}$, Shiwu Xiong ${ }^{3}$, Jianghua Tang ${ }^{1}$, Chunmei Li ${ }^{1}$, Ling Li ${ }^{1}$, Yunzhen Ma ${ }^{1}$, Fang Wang $^{1}$ \\ ${ }^{1}$ College of Agronomy/Engineering Research Centre of Cotton Ministry of Education, Xinjiang Agriculture University, Urumqi, Xinjiang, China \\ 2 Cash Crop Research Institute, Xinjiang Agricultural Academy, Urumqi, Xinjiang, China \\ ${ }^{3}$ State Key Laboratory of Cotton Biology, Institute of Cotton Research of Chinese Academy of Agricultural Sciences, Anyang, Henan, China \\ Corresponding Authors: Wenxiu Xu, Yabing Li \\ Email address: xjxwx@sina.com, criliyabing@163.com
}

Planting density affects crop microclimate and intra-plant competition, playing an important role on yield formation and resource use, especially in areas where the temperature resource is limiting such as in Xinjiang, China. However, more studies are needed to examine how the change in planting density affects the microclimate factors such as the fraction of light intercepted(FLI), air temperature $(T)$ and relative humidity $(\mathrm{RH})$ within different canopy layers, which in turn affect the boll number per plant (BNF), boll number per unit area (BNA), boll weight (BW), and boll-setting rate (BSR) at fruiting branch (FB) positions $\mathrm{FB}_{1-3}, \mathrm{FB}_{4-6}$, and $\mathrm{FB}_{\geq 7}$ in cotton To quantify the relationships between boll characteristics, yield, and microclimate factors, we conducted a 2-year field experiment in 2019-2020 in Xinjiang with six plant densities: 9 (P1), 12 (P2), 15 (P3), 18 (P4), 21 (P5), and 24(P6) plants $\cdot \mathrm{m}^{-2}$. With each 3 plants $\cdot \mathrm{m}^{-2}$ increase in density, the average $\mathrm{FLI}$ and $\mathrm{RH}$ across different canopy layers increased by 0.37 and $2.04 \%$, respectively, whereas $T$ decreased by $0.64^{\circ} \mathrm{C}$. The $\mathrm{BNF}$ at $\mathrm{FB}_{\geq 7}, \mathrm{FB}_{4-6}$, and $\mathrm{FB}_{1-3}$ decreased by $0.82,0.33$, and 0.5 , respectively. The highest BNA was observed in the upper and middle layers in the P4 treatment $\left(52.2\right.$ bolls $\left.\cdot \mathrm{m}^{-2}\right)$, and in the lowest canopy layer with the P5 $\left(66.5 \mathrm{bolls} \cdot \mathrm{m}^{-2}\right)$. The highest BW was measured in the middle canopy layer for P3, and the highest BSR was measured in the lower layer for P3. Plant density exhibited linear or quadratic relationships with FLI, T, and RH. Microclimate factors mainly affected the boll number in each layer, but had no significant effects on the BW in any layer or the BSR in the middle and lower layers. Cotton yield was non-linearly related to plant density. The 2-year maximum yield was achieved at a plant density of 21 plant $\cdot \mathrm{m}^{-2}$, but the yield increase compared to the yield with a density of 18 plants $\cdot \mathrm{m}^{-2}$ was only $0.28 \%$. Thus, we suggest that the optimal plant 
density for drip-irrigated cotton in Xinjiang is 18 plants $\mathrm{m}^{-2}$, which could help farmers grow machine-harvested cotton. 
1 Boll characteristics and yield of cotton in relation to the 2 canopy microclimate under varying plant densities in an 3 arid area

Na Zhang', Liwen Tian², Lu Feng ${ }^{3}$, Wenxiu Xu' ${ }^{1}$, Yabing $\mathrm{Li}^{3}$, Fangfang Xing ${ }^{3}$, Zhengyi

Fan $^{3}$, Shiwu Xiong ${ }^{3}$, Jianghua Tang ${ }^{1}$, Chunmei Li ${ }^{1}$, Ling Li ${ }^{1}$, Yunzhen $\mathrm{Ma}^{1}$ and Fang

Wang 1

${ }^{1}$ College of Agronomy/Engineering Research Centre of Cotton Ministry of Education, Xinjiang Agricultural University, Xinjiang, China

2 Cash Crop Research Institute of Xinjiang Agricultural Academy, Xinjiang, China

${ }^{3}$ State Key Laboratory of Cotton Biology/Institute of Cotton Research of Chinese Academy of Agricultural Sciences, Henan, China

Corresponding Author:

Wenxiu $\mathrm{Xu}^{1}$

311 Nongda East Road, Urumqi, Xinjiang, 830052, China

Email address: xjxwx@sina.com

Yabing $\mathrm{Li}^{2}$

38 Huanghe Avenue, Anyang, Henan 455000, China

Email address: criliyabing@163.com

22

23

\section{ABSTRACT}

Planting density affects crop microclimate and intra-plant competition, playing an important role on yield formation and resource use, especially in areas where the temperature resource is limiting such as in Xinjiang, China. However, more studies are needed to examine how the change in planting density affects the microclimate factors such as the fraction of light intercepted (FLI), air temperature (T) and relative humidity $(\mathrm{RH})$ within different canopy layers, which in turn affect the boll number per plant (BNF), boll number per unit area (BNA), boll weight $(\mathrm{BW})$, and boll-setting rate $(\mathrm{BSR})$ at fruiting branch $(\mathrm{FB})$ positions $\mathrm{FB}_{1-3}, \mathrm{FB}_{4-6}$, and $\mathrm{FB}_{\geq 7}$ in cotton. To quantify the relationships between boll characteristics, yield, and microclimate factors, we conducted a 2-year field experiment in 2019-2020 in Xinjiang with six plant densities: 9 (P1), $12(\mathrm{P} 2), 15(\mathrm{P} 3), 18(\mathrm{P} 4), 21(\mathrm{P} 5)$, and 24(P6) plants $\cdot \mathrm{m}^{-2}$. With each 3 plants $\cdot \mathrm{m}^{-2}$ increase in density, the average FLI and RH across different canopy layers increased by 0.37 and 2.04\%, respectively, whereas $\mathrm{T}$ decreased by $0.64^{\circ} \mathrm{C}$. The $\mathrm{BNF}$ at $\mathrm{FB}_{\geq 7}, \mathrm{FB}_{4-6}$, and $\mathrm{FB}_{1-3}$ decreased by $0.82,0.33$, and 0.5 , respectively. The highest BNA was observed in the upper and middle layers in the P4 treatment $\left(52.2\right.$ bolls $\left.\cdot \mathrm{m}^{-2}\right)$, and in the lowest canopy layer with the P5 $\left(66.5 \mathrm{bolls} \cdot \mathrm{m}^{-2}\right)$. 
37 The highest BW was measured in the middle canopy layer for P3, and the highest BSR was measured in the lower layer for P3. Plant density exhibited linear or quadratic relationships with FLI, T, and RH. Microclimate factors mainly affected the boll number in each layer, but had no significant effects on the BW in any layer or the BSR in the middle and lower layers. Cotton yield was non-linearly related to plant density. The average 2-year highest yield was achieved at a plant density of $21 \mathrm{plant} \cdot \mathrm{m}^{-2}$, but the yield increase compared to the yield with a density of 18 plants $\cdot \mathrm{m}^{-2}$ was only $0.28 \%$. Thus, we suggest that the optimal plant density for drip-irrigated cotton in Xinjiang is 18 plants $\mathrm{m}^{-2}$, which could help farmers grow machine-harvested cotton.

Keywords: Yield-density relationship; boll distribution; plant density; fraction of light intercepted; canopy temperature and humidity

\section{INTRODUCTION}

Cotton (Gossypium hirsutum L.) is an important cash crop grown worldwide as a major source of fibre (Constable et al., 2015). China is one of the largest producers and consumers of cotton globally (Mao et al., 2016). China's cotton imports, total supply, and use were higher than those of other cotton-producing nations including Brazil, India, and Pakistan (USDA, 2020). Xinjiang Uyghur Autonomous Region has become the most important cotton-growing region in China (Appiah et al., 2014; Tian et al., 2016). In 2020, the region produced 5.2 million tons of seed cotton from 2.5 million planted hectares (NBS, 2020), accounting for $87.33 \%$ of the production and $78.93 \%$ of the area planted in China. The average lint yield was $2063 \mathrm{~kg} \cdot \mathrm{ha}^{-1}$, benefiting from intensive management and new cotton varieties (Dai and Dong, 2014; Feng et al., 2017). In Xinjiang, cotton is grown at relatively high plant densities. While increasing plant density increases the cotton yield, it also increases intra-plant competition, resulting in increased shedding and rotten bolls(Bednarz, 2006; Bai et al., 2017). Considering yield and fibre quality for machine-harvested cotton, the cotton planting density must promote "easy, simplified, efficient, and sustainable" production (Dong et al., 2018). However, the optimal machineharvested plant density under drip irrigation is not clear.

Yield is the combined result of genetic factors and the external environment, whereas microenvironment variation within the canopy affects the ability of the crop to use available resources (Yang et al., 2014). Cotton yield and quality are more susceptible to microclimate 
67 conditions than other crops because the reproductive organs are distributed throughout the cotton 68 canopy (Schurr et al., 2006). Plant density has a strong effect on cotton yield components 69 (Bednarz et al., 2005; Darawsheh et al., 2009), canopy structure (Zhang et al., 2004; Dong et al., 70 2010; Kaggwa-Asiimwe et al., 2013; Chapepa et al., 2020), and light distribution, light 71 interception, air temperature, and humidity within the canopy (Brodrick, 2013; Yang et al., 2014; 72 Yao et al., 2016; Xue et al., 2017). Light interception plays a key role in photosynthesis, which is 73 enhanced by a greater photon flux density within the canopy (Aikman, 1989). Light interception 74 is always positively related to dry matter accumulation (Ajayakumar et al., 2017). High cotton 75 planting densities decrease the light distribution in the lower canopy (Brodrick et al., 2013). A 76 moderate planting density $\left(3.0\right.$ plants $\left.\cdot \mathrm{m}^{-2}\right)$ in the Yangtze River region, which has a mean daily

78

79

80

81

82

83 air temperature of $27.1^{\circ} \mathrm{C}$ and daily relative humidity of $79.7 \%$ from June to October, resulted in high cotton yields (Yang et al., 2014).

Agriculture has strong regional characteristics. The cotton planting density in Xinjiang ranges from 15 to 30 plants $\cdot \mathrm{m}^{-2}$ (Dong et al., 2018), which is much higher than in other cottonproducing regions in China. Different climatic conditions, planting densities, and management measures will inevitably result in different growth microclimates. Especially with intensifying climate warming, crop growth and yield are significantly affected (Cammarano and Tian, 2018; Fahad et al., 2021b). As part of the arid zone in central Asia, Xinjiang is extremely scarce of water resources and sensitive to global climate change(Yao et al., 2018). Since 1997, the climate in Xinjiang has shifted from warm and wet to warm and dry (Yao et al., 2021). Given the intensive management of high planting density cotton in Xinjiang's extremely arid climate, it is necessary to study how altering the planting density affects the cotton canopy microclimate and boll setting characteristics.

Cotton bolls located at different fruiting branch (FB) positions experience different climate conditions (Liu et al., 2015a) and boll weight and fibre quality differ at different FB positions (Zhao et al., 2011; Zhao and Oosterhuis, 2000). To assess the optimal plant density under drip irrigation with machine harvesting, we conducted a 2-year field experiment with planting densities of 9 to 24 plants $\cdot \mathrm{m}^{-2}$. Our objectives were to clarify the relationships among planting density, canopy microclimate, and yield under extremely arid conditions in Xinjiang and to determine optimal planting density for machine-harvested drip-irrigated cotton in Xinjiang. 


\section{MATERIALS AND METHODS}

\section{Experimental site}

99 The 2-year field experiment was conducted in 2019 to 2020 at the experimental station of the

100 Institute of Cotton Research of the Chinese Academy of Agricultural Sciences in Aral, Xinjiang

101 (4060’ $\mathrm{N}, 81^{\circ} 31^{\prime} \mathrm{E}$, altitude 1100 m.a.s.1.). The mean annual air temperature at the experimental 102 site ranges from $8.4^{\circ} \mathrm{C}$ to $11.4^{\circ} \mathrm{C}$, and the annual accumulated above $10^{\circ} \mathrm{C}$ ranges from $3450^{\circ} \mathrm{C}$ 103 to $4432^{\circ} \mathrm{C}$. The frost-free period lasts 180 to 221 days, and the mean annual precipitation is 48

$104 \mathrm{~mm}$. The monthly precipitation and mean temperature during the 2019 and 2020 cotton growing 105 seasons are shown in Table 1. The soil is sandy loam, and the soil nutrient concentrations at a 106 depth of $20 \mathrm{~cm}$ prior to sowing are listed in Table 2.

107 Experimental design and field management

108 The experiment was established using a randomized complete block design with three replicates 109 of each planting density of 9 (P1), 12 (P2), 15 (P3), 18 (P4), 21 (P5), and 24 (P6) plants $\cdot \mathrm{m}^{-2}$. The 110 plant distances for the six densities were 29.2, 21.9, 17.5, 14.6, 12.5, and $10.9 \mathrm{~cm}$, respectively.

111 The crop row orientation was north-south. Row spacing was wide+narrow i.e. $66 \mathrm{~cm}+10 \mathrm{~cm}$, 112 and the rows were covered with a $2.05 \mathrm{~m}$ wide transparent plastic film. Each plot was $47.9 \mathrm{~m}^{2}(7$ $113 \times 6.84 \mathrm{~m})$. The edges of the film were buried in the soil, leaving a $0.23 \mathrm{~m}$ wide bare soil between 114 each sheet. The planting pattern, drip irrigation layout and film cover are illustrated in Figure 1.

115 The cultivar used in the experiment was hybrid cotton variety CRI88 with a growth duration 116 of approximately 136 days. Cotton was sown on 18 April 2019 and 21 April 2020 using the 117 manual hill-drop method after covering the rows with plastic film. Seedlings were manually 118 thinned at the two-leaf stage to obtain the desired planting densities. The buds of the main stem 119 were topped on 17 July 2019 and 13 July 2020. The cotton was harvested on 15 October 2019 120 and 03 October 2020. Before sowing, fertilizer was applied at $4.8 \mathrm{t} \cdot \mathrm{ha}^{-1}$ organic fertilizer, 225 $121 \mathrm{~kg} \cdot \mathrm{ha}^{-1}$ urea $(46.4 \% \mathrm{~N})$, and $300 \mathrm{~kg} \cdot \mathrm{ha}^{-1}$ primary calcium phosphate $\left(46 \% \mathrm{P}_{2} \mathrm{O}_{5}\right)$. Fertilizer 122 consisting of $150 \mathrm{~kg} \cdot \mathrm{ha}^{-1}$ urea, $270 \mathrm{~kg} \cdot \mathrm{ha}^{-1}$ diammonium phosphate $\left(18 \% \mathrm{~N}, 46 \% \mathrm{P}_{2} \mathrm{O}_{5}\right)$, and $123112.5 \mathrm{~kg} \cdot \mathrm{ha}^{-1}$ potassium dihydrogen phosphate $\left(52 \% \mathrm{P}_{2} \mathrm{O}_{5}, 34 \% \mathrm{~K}_{2} \mathrm{O}\right)$ was applied as a top 124 dressing with each irrigation. The plots were irrigated nine times over the growing period with a 125 total of $4200 \mathrm{~m}^{3} \cdot \mathrm{ha}^{-1}$. Other management actions followed the local farming practices.

126 Data collection

127 Fraction of light intercepted within the canopy Fraction of light intercepted (FLI) within the 128 canopy was evaluated from the budding to boll opening stage in 2019 and 2020. Incident 
129 photosynthetically active radiation $\left(\mathrm{PAR}_{0}\right)$ and transmitted photosynthetically active radiation 130 (PARc) were measured using a LI-191SA light quantum sensor and a LI-1400 data logger (LI131 COR, Lincoln, NE, USA). The canopy was divided into $0.2 \mathrm{~m} \times 0.2 \mathrm{~m}$ vertical and horizontal 132 grids. The quantum sensor was placed perpendicular to the rows, and three replicate 133 photosynthetically active radiation measurements were taken in each plot. The intercepted light 134 rate (Ir) of each sensor was computed using Equation (1). FLI was computed according to the 135 Simpson 3/8 integration rule (Xue et al., 2017), using Equations (2) and (3), where $A_{i}$ is the 136 amount of light in a certain cross-sectional area, the coefficient vector is $137\{1,3,3,2,3,3,2, \ldots, 3,3,2,1\}, \Delta x$ is the vertical interval of the grid, $\Delta y$ is the horizontal interval, $i$ and $138 j$ are grid node numbers, and $G_{(i, j)}$ represents kriging interpolation points, FLI is the total light 139 interception rate in the certain area of the canoy. The canopy was divided into lower, middle, and 140 upper layers as shown in Figure 2.

$$
\begin{aligned}
& I r=1-P A R c / P A R_{0} \\
& A i=\frac{3 \Delta \mathrm{x}}{8}\left[G_{i, 1}+3 G_{i, 2}+3 G_{i, 3}+2 G_{i, 4}+\ldots+2 G_{i, n c o l-1}+G_{i, n c o l}\right] \\
& F L I \approx \frac{3 \Delta \mathrm{y}}{8}\left[A_{1}+3 A_{2}+3 A_{3}+2 A_{4}+\ldots+2 A_{\text {ncol }-1}+A_{\text {ncol }}\right]
\end{aligned}
$$

141 Canopy air temperature and relative humidity Canopy air temperatuer (T) and relative

142 humidity (RH) were monitored with an automatic Lascar EL-USB-2 data logger (Lascar

143 Electronics, Erie, PA, USA). The sensors were installed at approximately $1 / 3,1 / 2$, and $2 / 3$ of the 144 canopy height at the position between wide and narrow rows at full squaring, and at the second $145 \mathrm{FB}\left(\mathrm{FB}_{2}\right)$, fifth $\mathrm{FB}\left(\mathrm{FB}_{5}\right)$, and eighth $\mathrm{FB}\left(\mathrm{FB}_{8}\right)$ after the full blooming period. The data recorded 146 every $30 \mathrm{~min}$ from 10:00 to 21:00 and averaged to daily mean values.

147 Spatial boll distribution On 10 October 2019 and 28 Septemper 2020, 30 plants in each plot

148 were selected to determine the spatial boll distribution. Bolls were divided into three groups 149 according to whether they were found on FBs 1-3 (FB $1-3)$, FBs 4-6 (FB 4-6 $)$, and FBs higher than $1507\left(\mathrm{FB}_{\geq 7}\right)$. Bolls number per plant were collected from $\mathrm{FB}_{1-3}, \mathrm{FB}_{4-6}$, and $\mathrm{FB}_{\geq 7}$ in each plot. The 151 boll-setting rate (BSR) for different FBs was equal to number of setting bollsdivided by the total 152 number of fruit nodes. Individual boll weights (BWs) at different FBs were determined after 153 drying the bolls in the sun to a constant weight.

154 Seed cotton yield Seed cotton in the area of $14.35 \mathrm{~m}^{2}(7 \times 2.05 \mathrm{~m})$ with three repetitions were 155 handpicked on 15 October 2019 and 3 October 2020, and weighed after sun-drying. 


\section{Data analyses}

157 SPSS 25.0 software (SPSS Inc., Chicago, IL, USA) was used to run non-linear regression and ANOVA.

158 The least significant difference (LSD) test at the 0.05 level was used to compare the mean of different

159 treatments. Graphics were created using origin 2018 graphics software (Origin LabInc., Northampton, 160 MASS, USA).

\section{RESULTS}

\section{FLI within the canopy}

163 FLI within the canopy increased with the planting density, but decreased with the increase in canopy height (Fig. 3). Over the entire growth period, the maximum FLI in the upper layer was observed in the P5 (0.66) in the full-boll period in 2019 and in the P6 (0.35) in the full blooming period in 2020. P5 produced the highest 2-year average FLI in the middle $(0.85)$ and lower layers (0.97) in the full-blooming period. Compared with the peak value in each treatment, FLI was reduced by $0.25-0.39,0.17-0.40$, and $0.07-0.30$ in the upper, middle, and lower canopies, respectively, at the boll-opening period. Among the different planting densities, P1 and P2 resulted in the greatest FLI reduction in the upper layer, whereas the smallest FLI reduction was in P4 and occurred in the middle and lower layers.

\section{Distribution of air $\mathbf{T}$ within the canopy}

173 Consistent with changes in the outside air T (control $[\mathrm{CK}]$ ), the air T within the canopy increased and then decreased over the course of the growing season in both years (Fig. 4). For all

175 treatments, $\mathrm{T}$ was higher than CK in the upper canopy layer. The higher the planting density, the 176 lower the $\mathrm{T}$ within the canopy. Increasing the planting density not only advanced the time when 177 the cooling effect appeared but also increased the cooling rate. At the middle canopy layer, the $\mathrm{T}$ 178 of $\mathrm{P} 6$ at the full-blooming stage was $0.31^{\circ} \mathrm{C}$ lower than $\mathrm{CK}$, while that for $\mathrm{P} 5$ was $0.16^{\circ} \mathrm{C}$ lower 179 than $\mathrm{CK}$ at the full-boll stage. In the lower layer, Ts of P4, P5, and P6 at the full-blooming stage were $1.68,1.64$, and $2.11^{\circ} \mathrm{C}$ lower than $\mathrm{CK}$, respectively, while $\mathrm{T}$ at $\mathrm{P} 3$ was $0.87^{\circ} \mathrm{C}$ lower than $\mathrm{CK}$ at the full-boll stage.

$\mathrm{T}$ was higher in the upper canopy layer than in the middle and lower layers, but the depression in $\mathrm{T}$ was greater between the upper and middle layers than that between the middle and lower layers. Over the 2 years, the $\mathrm{T}$ in the middle canopy layer in the P1-P6 treatments was 4.21, 
187 Distribution of RH within the canopy

188 Across canopy layers, RH was highest during the full-boll period (Fig. 5). The peak RH in the 189 upper, middle, and lower layers was 51.66, 63.88, and 70.57\% in 2019, respectively, and 52.83, 19064.69 , and $71.84 \%$ in 2020. At boll opening, the respective RH values decreased by 33.85, 36.10, 191 and $37.92 \%$ in 2019, and 33.31, 39.65, and 41.84\% in 2020 when compared to peak values.

192 Contrary to the variation in T within the canopy, RH throughout the canopy increased with 193 planting density. In the upper layer, the canopy RH was higher than CK in the P5 and P6 plots, 194 whereas it was lower than CK in the P1 plot depending on the growth period. In the middle and 195 lower layers, the canopy RH of all treatments was higher than CK. As the planting density 196 increased, the amplitude of RH variation between the middle and upper layers decreased. The 2197 year average RH depression over the entire growth period was 10.16, 10.22, 9.39, 9.02, 8.14, and $1988.45 \%$ for plots P1 to P6, respectively. The amplitude of RH variation between the middle and 199 lower layers showed no particular trend.

200 Boll density, single boll weight, and boll setting rate at different FB positions

201 Increasing the density reduced the number of bolls at different FB positions (Table 3). With each 202 3-plants $\cdot \mathrm{m}^{-2}$ increment, the mean boll number per plant $(\mathrm{BNF})$ at $\mathrm{FB}_{\geq 7}, \mathrm{FB}_{4-6}$, and $\mathrm{FB}_{1-3}$ 203 decreased by $0.83,0.33$, and 0.5 in 2019 and $0.86,0.55$, and 0.38 in 2020, respectively. BNF in 204 plots P1 and P2 differed significantly from BNF in the P5 and P6 plots $(P<0.05)$ at different FB 205 positions. $\mathrm{At}_{\mathrm{FB}}$, the maximum boll number per area (BNA) was greatest in P4 plots in 2019 206 and P3 plots in 2020, and these maxima were significantly higher than those in the P5 and P6 207 plots $(P<0.05)$. At $\mathrm{FB}_{4-6}$, the BNA in P4 plots was significantly higher than those in P1 and P2 208 plots $(P<0.05)$, with maxima of $63.0 \mathrm{bolls} \cdot \mathrm{m}^{-2}$ in 2019 and $64.8 \mathrm{bolls} \cdot \mathrm{m}^{-2}$ in 2020 . At $\mathrm{FB}_{1-3}$, the 209 2-year average BNA was highest in P5 plots (73.19 bolls $\left.\cdot \mathrm{m}^{-2}\right)$, and it was also significantly 210 higher than the BNA in $\mathrm{P} 1$ and $\mathrm{P} 2$ plots $(P<0.05)$ but not significantly different from the BNA 211 in P6 plots. Boll-setting rates (BSR) declined in the order $\mathrm{FB}_{1-3}>\mathrm{FB}_{4-6}>\mathrm{FB}_{\geq 7}$. With values of

$21276.48 \%$ at $\mathrm{FB}_{1-3}$ and 59.89\% at $\mathrm{FB}_{4-6}$, the 2-year average BSR in P3 plots was significantly

213 higher than those in the other treatments $(P<0.05)$.

\section{Relationships of planting density to FLI, T, and RH}

215 Under different planting densities, FLI in the middle canopy layer and T and RH in all canopy 216 layers showed linear relationships with planting density. The relationship between FLI in the 217 upper and lower layers and density followed a quadratic curve pattern (Fig. 6). Regression fits 218 are shown in Table 4. Increasing the density had no significant effect on FLI in the upper canopy 
219 layer. There was a positive linear relationship between density and FLI in the middle layer, and a 220 significant, negatively correlated conic relationship with FLI in the lower layer. T in each canopy 221 layer declined with increased planting density, whereas RH increased.

\section{Correlations among canopy FLI, T, RH, BNF, BNA, BW, and BSR}

223 As shown in Figure 7, canopy $\mathrm{T}$ and RH in each layer were negatively correlated. In the upper 224 layer, FLI was uncorrelated with T, RH, BNF, BNA, BW, and BSR. T was positively correlated 225 with BNF, BNA, and BSR, whereas RH was negatively correlated with BNF and BSR. In the 226 middle and lower layers, FLI was negatively correlated with $\mathrm{T}$ and BNF but positively correlated 227 with RH and BNA. T was positively correlated with BNF but negatively correlated with BNA. 228 RH was negatively correlated with BNF and positively correlated with BNA only in the lower 229 canopy layer.

230 Significant interactions between the boll number, BW, and BSR were mainly found for the 231 upper canopy layer. Among them, BSR was positively correlated with BNF, BNA, and BW,

232 BNF was positively correlated with BNA, and BNA was positively correlated with BW.

233 Yield

234 Yield varied greatly with planting density (Fig. 8). The average 2 -year yield increased by 0.28

$23524.33 \%$ when the planting density increased from 9 plants $\cdot \mathrm{m}^{-2}(\mathrm{P} 1)$ to 21 plants $\cdot \mathrm{m}^{-2}(\mathrm{P} 5)$. The

236 highest yields were seen for P5 of $6644.52 \mathrm{~kg} \cdot \mathrm{ha}^{-1}$ in 2019 and P4 of $6517.26 \mathrm{~kg} \cdot \mathrm{ha}^{-1}$ in 2020.

237 There was no significant difference in the yields of P4 and P5 $(P>0.05)$, but they were

238 significantly higher than the yields obtained in P1, P2, P3, and P6 in both years $(P<0.05)$. The 239 relationship between yield and planting density is shown in Figure 9. The fitting curve was 240 parabolic and opened downwards, and the fitting coefficients $R^{2}$ were all higher than $0.9(P<$ 241 0.01). The curve simulation also showed that the $\mathrm{P} 4\left(18\right.$ plants $\left.\cdot \mathrm{m}^{-2}\right)$ treatment had the maximum 242 yield.

\section{DISCUSSION}

244 Higher plant density utilized solar radiation, nutrients and space, which ultimately improved the 245 seed cotton yield. Although there were differences in the 2 years, the yield first increased with 246 the plant density and then decreased (Fig. 9). It was highest at planting densities of 18 or 21 247 plants $\cdot \mathrm{m}^{-2}$, but the difference between the two treatments was not significant (Fig. 8). This 248 substantiates the common opinion that increasing the planting density will not make the yield 
249 continue to increase. The yield remained approximately the same or even decreased after a 250 certain threshold was reached. The boll distribution at lower plant density increased the bolls at $251 \quad \mathrm{FB}_{\geq 7}$, mainly because low-density treatment produced more bolls per plant with more FBs and 252 stem nodes, which enabled more source and sink connections. Boll number per $\mathrm{m}^{2}$ (except FB $\mathrm{FB}_{\geq 7}$ ), $253 \mathrm{BW}$, and BSR at different $\mathrm{FB}_{\mathrm{S}}$ were all highest at 15 or 18 plants $\cdot \mathrm{m}^{-2}$ (Table 3). These three 254 indicators decreased to varying degrees when the planting density exceeded 18 plants $\cdot \mathrm{m}^{-2}$. The 255 yield and boll characteristics were not as good under the crowded conditions encountered at high 256 densities. This may be caused by intensified competition for limited resources and the 257 impoverished environment (Li et al., 2020).

258 More light was intercepted at higher planting densities in different canopy layers. This 259 confirms the view that high planting densities can help with achieving high levels of radiation 260 261 262 263 264 265 266 267 268 interception by the crop (Mao et al., 2014; Zhang et al., 2014). The vertical distribution of light within the canopy was not uniform; it was highest in the lower canopy layer and lowest in the upper layers (Fig. 3). A dense canopy with a high leaf area index was the main reason for the difference (Xue et al., 2017). Moreover, we also showed that the highest light interception rate does not result in the highest yield. Due to the seed cotton yield was relation to light penetration and ventilation into the lower levels of the canopy (Kaggwa-Asiimwe et al,. 2013; Zhi et al., 2014). An appropriate density allows greater light penetration and gaseous exchange (Meredith, 1984), which improves the utilization of light resources and maintains high crop productivity, and assists in the development of bolls in the canopy (Chapepa et al., 2020).

Plant density alters the characteristics of the boundary between the leaves and surrounding air, as well as affecting canopy $\mathrm{T}$ and $\mathrm{RH}$. Higher yields were obtained at a lower canopy $\mathrm{T}$ (Han et al., 2007; Fan et al., 2007), and canopy T and yield were negatively correlated in wheat (Amani et al., 1996). In our study, there was negatively correlation between $\mathrm{T}$ and plant density, while the RH and plant density was positively correlated (Table 4), which means that $\mathrm{T}$ in the different canopy layers decreased with increasing planting density (Fig. 4), whereas RH increased (Fig. 5). This may be due to the fact the ground in high plant density is shaded from the sun, and the evapotranspiration is higher in higher plant density, resulting in lower canopy $\mathrm{T}$. While lower plant density with an open canopy could allow more air flow for evaporation, thereby reducing RH. Therefore, increasing plant density played a significant role in cooling and humidifying the canopy environment. 
280

281

282

283

284

285

286

287

288

289

290

291

292

293

294

295

296

297

298

299

300

301

302

303

304

305

306

307

308

We also found that compared with BW and BSR, boll number was significantly affected by canopy FLI, T, and RH (Fig. 7). Of these, FLI and RH were negatively related to boll number at the single-plant level, but positively related to population boll number, while the relationship between $\mathrm{T}$ and boll number was opposite that of $\mathrm{RH}$. This means that the canopy microclimate of lower T, higher RH, and higher FLI formed at higher planting densities, especially in the middle and lower canopy layers, was not conducive to boll retention. This also explained why BW and BSR in the middle and lower canopy layers of the 18 and 21 plants $\cdot \mathrm{m}^{-2}$ treatments were lower than in the other treatments.

\section{CONCLUSIONS}

Increasing the planting density resulted in increased FLI and RH and a decrease in T in different canopy layers. Microclimate factors mainly affected the boll number in each layer significantly, but had no significant effects on BW in any layer or BSR in the middle and lower layers. The canopy microclimate of lower T, higher RH, and higher FLI formed at high planting densities negatively affected boll number, BW, and BSR. Although the 2-year average seed cotton yield was highest at 21 plants $\cdot \mathrm{m}^{-2}$, it was only $0.28 \%$ higher than at 18 plants $\cdot \mathrm{m}^{-2}$, and the difference was not significant $(P>0.05)$. Thus, we suggest that when using a $66 \mathrm{~cm}+10 \mathrm{~cm}$ planting pattern with drip irrigation and film mulching in Xinjiang, the appropriate planting density is 18 plants $\cdot \mathrm{m}^{-2}$.

\section{ACKNOWLEDGEMENTS}

This work was supported by the National Key Research and Development Program of China (2020YFD1001001). We thank the reviewers Shah Fahad and Muahammad Tehseen Azhar, professors Lizhen Zhang, Honghai Luo and Penghao Wu for their constructive comments on a previous version of this manuscript.

\section{REFERENCES}

Aikman DP. 1989. Potential increase in photosynthetic efficiency from the redistribution of solar radiation in a crop. Journal of Experimental Botany, 40(217), 855-864

Ajayakumar MY, Umesh MR, Shivaleela S, Nidagundi JM. 2017. Light interception and yield response of cotton varieties to high density planting and fertilizers in sub-tropical India. Journal of applied and natural science, 9(3), 1835-1839 DOI 10.31018/jans.v9i3.1448. 
Amani I, Fischer RA, Reynolds MP. 1996. Canopy temperature depression association with yield of irrigated spring wheat cultivars in a hot climate. Journal of Agronomy and Crop Science, 176(2), 119-129 DOI 10.1111/j.1439-037X.1996.tb00454.x

Appiah MK, Feike T, Wiredu AN, Mamitimin Y. 2014. Cotton production, land use change and resource competition in the Aksu-Tarim River Basin Xinjiang, China. Quarterly Journal of International Agriculture, 53(3), 243-261

Bai Y, Mao SC, Tian LW, Li L, Dong HZ. 2017. Advances and prospects of high-yielding and simplified cotton cultivation technology in Xinjiang cotton growing area. Scientia Agricultura Sinica, 50(1), 38-50 (in chinese) DOI 10.3864/j.issn.0578-1752.2017.01.004

Bednarz CW, Shurley WD, Anthony WS, Nichols RL. 2005. Yield, quality, and profitability of cotton produced at varying plant densities. Agronomy Journal, 97(1), 235240 DOI 10.1051/agro:2004062

Bednarz CW, Nichols RL, Brown SM. 2006. Plant density modifications of cotton within-boll yield components. Crop Science, 46(5), 2076-2080 DOI 10.2135/cropsci2005.12.0493

Brodrick R, Bange MP, Milroy SP, Hammer GL. 2013. Physiological determinants of high yielding ultra-narrow row cotton: Canopy development and radiation use efficiency. Field Crops Research, 148, 86-94 DOI 10.1016/j.fcr.2012.05.008

Chapepa B, Mudada N, Mapuranga R. 2020. The impact of plant density and spatial arrangement on light interception on cotton crop and seed cotton yield:an overview. Journal of Cotton Research, 3(1), 210-215 DOI 10.1186/s42397-020-00059-z

Constable G A, Bange M P. 2015. The yield potential of cotton (Gossypium hirsutum L.). Field Crops Research, 182, 98-106 DOI 10.1016/j.fcr.2015.07.017

Dai JL, Dong HZ. 2014. Intensive cotton farming technologies in China: achievements, challenges and countermeasures. Field Crops Research, 155, 99-110 DOI 10.1016/j.fcr.2013.09.017

Darawsheh MK, Khah EM, Aivalakis G, Chachalis D, Sallaku F. 2009. Cotton Row Spacing and Plant Density Cropping Systems. I. Effects on accumulation and partitioning of dry mass and LAI. Journal of Food, Agriculture and Environment, 7(3\&4), 258-261 DOI $10.3168 /$ jds.2009-92-7-3543

Dong HZ, Kong XQ, Li WJ, Tang W, Zhang DM, 2010. Effects of plant density and nitrogen and potassium fertilization on cotton yield and uptake of major nutrients in two fields with varying fertility. Field Crops Research, 119, 106-113 DOI 10.1016/j.fcr.2010.06.019

Dong HZ, Li WJ, Zhang WF, 2018. Light and Simplified Cotton Planting. Beijing: China Agricultural Press.

Dong HZ, Zhang YJ, Zhang DM, Dai JL, Zhang WF. 2018. New grouped harvesting-based population structures of cotton. Scientia Agricultura Sinica, 51(24), 4615-4624. (in Chinese) DOI 10.3864/j.issn.0578-1752.2018.24.003

Fahad, S., Sonmez, O., Saud, S., Wang, D., Wu, C., Adnan, M., Turan, V. (Eds.), 2021 b. Climate change and plants: biodiversity, growth and interactions, First edition. ed, Footprints of climate variability on plant diversity. CRC Press, Boca Raton.

Fan TL, Song SY, Xu YP, Li XM. 2007. Relationship between canopy temperature and water use efficiency/grain yield among dryland winter wheat genotypes during grain filling stage. Acta Ecologica Sinica, 27(11), 4491-4497 (in Chinese) DOI 10.3321/j.issn:10000933.2007.11.015 
353

354

355

356

357

358

359

360

361

362

363

364

365

366

367

368

369

370

371

372

373

374

375

376

377

378

379

380

381

382

383

384

385

386

387

388

389

390

391

392

393

394

395

396

397

398

Feng L, Dai JL, Tian LW, Zhang HJ, Li WJ, Dong HZ. 2017. Review of the technology for high-yielding and efficient cotton cultivation in the northwest inland cotton-growing region of China. Field Crops Research, 208, 18-26 DOI 10.1016/j.fcr.2017.03.008

Han L, Wang CF, Wang J, Li YY, Zhou XL. 2007. The study on differences of the canopy temperature and physiological characteristics of cotton. Acta Agriculturae Borealioccidentalis Sinica, 16(03), 85-88 (in Chinese)

Kaggwa Asiimwe R, Andrade Sanchez P, Wang GY. 2013. Plant architecture influences growth and yield response of upland cotton to population density. Field Crops Research, 145, 52-59 DOI 10.1016/j.fcr.2013.02.005

Li XF, Han YC, Wang GP, Feng L, Wang ZB, Yang BF, Du WL, Lei YP, Xiong SW, Zhi XY, Xing FF, Fan ZY, Xin MH, Li YB. 2020. Response of cotton fruit growth, intraspecific competition and yield to plant density. European Journal of Agronomy, 114, 125991. DOI 10.1016/j.eja.2019.125991

Liu J, Meng Y, Chen J, Lü F, Ma Y, Chen B, Wang Y, Zhou Z, Oosterhuis DM. 2015. Effect of late planting and shading on cotton yield and fiber quality formation. Field Crops Research, 183, 1-13 DOI 10.1016/j.fcr.2015.07.008

Mao LL, Zhang LZ, Zhao XH, Liu SD, Vander Werf W, Zhang SP, Spiertz H, Li ZH. 2014. Crop growth, light utilization and yield of relay intercropped cotton as affected by plant density and a plant growth regulator. Field Crops Research, 155,67-76

DOI 10.1016/j.fcr.2013.09.021

Mao SC, Li FG. 2016. Contemporary World Cotton. China Agriculture Press, Beijing,pp. 713715 (in Chinese).

Meredith WR. 1984. Influence of leaf morphology on lint yield on cotton-enhancement by the sub okra trait1. Crop Science, 24(5), 855-857

DOI 10.2135/cropsci1984.0011183x002400050007x

NBS, National Bureau of statistics of the People's Republic of China, 2020. Announcement of National Bureau of Statistics on Cotton Yield in 2020. http://www.stats.gov.cn/tjjj/zxfb/202012/t20201218_1810113.html

Reddy KR, Hodges HF, McKinion JM. 1995. Carbon dioxide and temperature effects on pima cotton growth. Agriculture, Ecosystem and Environment, 54(1-2), 17-29 DOI 10.1016/0167-8809(95)00593-H

Schurr U, Walter A, Rascher U. 2006. Functional dynamics of plant growth and photosynthesis from steady-state to dynamics from homogeneity to heterogeneity. Plant Cell and Environment, 29(3), 340-352 DOI 10.1111/j.1365-3040.2005.01490.x

Tian XM, Li XY, Lv X, Li BC, Chen GW. 2016. Principles and Modern Technologies of Cotton Farming in Xinjiang. Science Press, Beijing, pp. 182-381,1-44

USDA, United States Department of Agriculture, 2020. Foreign Agricultural Service System: Production, Supply and Distribution. http://www.fas.usda.gov/psdonline/psdQuery.aspx.

Xue HY, Han YC, Li YB, Wang GP, Feng L, Fan ZY, Du WL, Yang BF, Mao SC. 2017. Estimating light interception using the color attributes of digital images of cotton canopies. Journal of Integrative Agriculture, 16(7), 1474-1485 DOI 10.1016/S2095-3119(16)61542-3

Xue J, Gou L, Shi ZG, Zhao YS, Zhang WF. 2017. Effect of leaf removal on photosynthetically active radiation distribution in maize canopy and stalk strength. Journal of Integrative Agriculture, 16(01), 85-96 DOI 10.1016/S2095-3119(16)61394-1

Yang GZ, Luo XJ, Nie YC, Zhang XL. 2014. Effects of Plant Density on Yield and Canopy Micro Environment in Hybrid Cotton. Journal of Integrative Agriculture, 13(10): 2154-2163

Peer) reviewing PDF | (2021:05:61381:1:1:NEW 24 Jul 2021) 
DOI 10.1016/S2095-3119(13)60727-3

Yao HS, Zhang YL, Yi XP, Zuo WQ, Lei ZY, Sui LL, Zhang WF. 2017. Characters in lightresponse curves of canopy photosynthetic use efficiency of light and $\mathrm{N}$ in responses to plant density in field-grown cotton. Field Crops Research, 203, 192-200 DOI 10.1016/j.fcr.2016.12.018

Yao JQ, Zhao Y, Chen YN, Yu XJ, Zhang RB. 2018. Multi- scale assessments of droughts: A case study in Xinjiang, China. Science of the Total Environment, 630, 444-452. DOI 10.1016/j.scitotenv.2018.02.200Get rights and content

Yao JQ, Mao WY, Chen J, Dilinuer T. 2021. Signal and impact of wet-to-dry shift over Xinjiang, China. Acta Geographica Sinica, 76(1), 57-72 (in Chinese) DOI: $10.11821 / \mathrm{dl}$ xb202101005

Zhang DS, Zhang LZ, Liu JG, Han S, Wang Q, Evers J, Liu J, Vander Werf W, Li L. 2014. Plant density affects light interception and yield in cotton grown as companion crop in young jujube plantations. Field Crops Research, 169, 132-139 DOI 10.1016/j.fcr.2014.09.001

Zhang WF, Wang ZL, Yu SL, Li SH, Fang J, Tong WS. 2004. Effects of planting density on canopy photosynthesis, canopy structure and yield formation of high-yield cotton in Xinjiang, China. Chinese Journal of Plant Ecology, 28(2), 164-171 (in Chinese) DOI 10.17521/cjpe.2004.0024

Zhao D, Oosterhuis DM. 2000. Dynamics of non-structural carbohydrates in developing leaves, bracts and floral buds of cotton. Environmental and Experimental Botany, 43(3), 185-195 DOI 10.1016/S0098-8472(99)00059-3

Zhao WQ, Meng YL, Chen BL, Wang YH, Li WF, Zhou ZG. 2011. Effects of fruitingbranch position, temperature-light factors and nitrogen rates on cotton (Gossypium hirsutum L.) fiber strength formation. Scientia Agricultura Sinica, 44(18), 3721-3732 (in Chinese) DOI 10.3864/j.issn.0578-1752.2011.18.003

Zhi XY, Han YC, Mao SC, Wang GP, Feng, Yang BF, Fan ZY, Du WL, Lu JH, Li YB. 2014. Light spatial distribution in the canopy and crop development in cotton. Plos One. 9(11):e113409. DOI 10.1371/journal.pone.0113409. 


\section{Table $\mathbf{1}$ (on next page)}

Meteorological conditions during the cotton growing seasons in 2019 and 2020 
1 Table 1 Meteorological conditions during the cotton growing seasons in 2019 and 2020.

\begin{tabular}{ccccccccc}
\hline Variable & Year & April & May & June & July & August & September & October \\
\hline $\begin{array}{c}\text { Precipitation } \\
(\mathrm{mm})\end{array}$ & 2019 & 4.70 & 16.70 & 28.70 & 3.20 & 13.60 & 26.10 & 0.00 \\
& & & & & & & & \\
& 2020 & 0.20 & 0.00 & 7.40 & 13.20 & 4.80 & 1.60 & - \\
$\begin{array}{c}\text { Mean temperature } \\
\left({ }^{\circ} \mathrm{C}\right)\end{array}$ & 2019 & 19.00 & 19.80 & 22.60 & 26.80 & 24.90 & 19.50 & 12.20 \\
& & & & & & & & \\
& 2020 & 17.07 & 20.78 & 22.80 & 23.30 & 23.60 & 19.10 & - \\
\hline
\end{tabular}

2 
Table 2 (on next page)

Nutrient contents of the experimental plot soil in 2019 and 2020. 
1 Table 2 Nutrient contents of the experimental plot soil in 2019 and 2020.

\begin{tabular}{cccccc}
\hline Year & $\begin{array}{c}\text { Total nitrogen } \\
\left(\mathrm{g} \cdot \mathrm{kg}^{-1}\right)\end{array}$ & $\begin{array}{c}\text { Organic matter } \\
\left(\mathrm{g} \cdot \mathrm{kg}^{-1}\right)\end{array}$ & $\begin{array}{c}\text { Available nitrogen } \\
\left(\mathrm{mg} \cdot \mathrm{kg}^{-1}\right)\end{array}$ & $\begin{array}{c}\text { Available phosphorous } \\
\left(\mathrm{mg} \cdot \mathrm{kg}^{-1}\right)\end{array}$ & $\begin{array}{c}\text { Available potassium } \\
\left(\mathrm{mg} \cdot \mathrm{kg}^{-1}\right)\end{array}$ \\
\hline 2019 & 0.40 & 9.98 & 21.00 & 32.01 & 72.00 \\
2020 & 0.48 & 10.02 & 51.40 & 36.70 & 94.00 \\
\hline
\end{tabular}

2 


\section{Table 3 (on next page)}

Effects of planting density on boll number and boll weight at different fruiting branch position in 2019 and 2020.

Each value represents the average of three replications. Values followed by a different letter in the same column are significantly different at $P=0.05$ level. 
1 Table 3 Effects of planting density on boll number and boll weight at different fruiting 2 branch position in 2019 and 2020.

\begin{tabular}{|c|c|c|c|c|c|c|c|c|}
\hline \multirow{3}{*}{$\begin{array}{l}\text { Fruiting branch } \\
\qquad \text { (FB) }\end{array}$} & \multicolumn{4}{|c|}{ Boll number } & \multicolumn{2}{|c|}{ Boll weight } & \multicolumn{2}{|c|}{ Boll setting ratio } \\
\hline & \multirow{2}{*}{ Treatment } & \multicolumn{2}{|c|}{ (per plant) } & $\left(\right.$ per $\left.m^{2}\right)$ & \multicolumn{2}{|c|}{ (g/boll) } & \multicolumn{2}{|c|}{$(\%)$} \\
\hline & & 2019 & 2020 & 20192020 & 2019 & 2020 & 2019 & 2020 \\
\hline \multirow[t]{6}{*}{$\mathrm{FB}_{1-3}$} & $\mathrm{P} 1$ & $5.03 \mathrm{a}$ & $5.17 \mathrm{a}$ & $45.27 \mathrm{c} \quad 46.53 \mathrm{c}$ & $6.13 \mathrm{c}$ & $6.07 \mathrm{c}$ & $62.92 \mathrm{ab}$ & $70.14 \mathrm{c}$ \\
\hline & $\mathrm{P} 2$ & $4.93 \mathrm{a}$ & $4.93 \mathrm{a}$ & 59.16 b $59.16 b$ & $6.34 \mathrm{bc}$ & $6.48 \mathrm{~b}$ & $64.91 \mathrm{a}$ & $78.72 \mathrm{~b}$ \\
\hline & P3 & $3.93 \mathrm{~b}$ & $5.03 \mathrm{a}$ & $58.95 \mathrm{~b} \quad 75.45 \mathrm{a}$ & $6.87 \mathrm{a}$ & $6.94 \mathrm{a}$ & $68.60 \mathrm{a}$ & $84.36 \mathrm{a}$ \\
\hline & $\mathrm{P} 4$ & $3.23 \mathrm{c}$ & $4.40 \mathrm{~b}$ & 58.14 b $79.20 \mathrm{a}$ & $6.64 \mathrm{ab}$ & $6.63 \mathrm{~b}$ & $61.78 \mathrm{~b}$ & $80.00 \mathrm{ab}$ \\
\hline & P5 & $3.17 \mathrm{c}$ & $3.80 \mathrm{c}$ & 66.57 a 79.80 a & $6.07 \mathrm{c}$ & $6.16 \mathrm{c}$ & $67.38 \mathrm{a}$ & $69.09 \mathrm{c}$ \\
\hline & P6 & $2.53 \mathrm{~d}$ & $3.27 \mathrm{~d}$ & $60.72 \mathrm{ab} 78.48 \mathrm{a}$ & $6.16 \mathrm{c}$ & $6.34 \mathrm{bc}$ & $64.96 \mathrm{a}$ & $58.33 \mathrm{~d}$ \\
\hline \multirow[t]{6}{*}{$\mathrm{FB}_{4-6}$} & $\mathrm{P} 1$ & $4.07 \mathrm{~b}$ & $5.23 \mathrm{a}$ & $36.63 \mathrm{~d} 47.07 \mathrm{c}$ & $7.00 \mathrm{a}$ & $6.92 \mathrm{ab}$ & $41.78 \mathrm{~d}$ & $58.80 \mathrm{a}$ \\
\hline & $\mathrm{P} 2$ & $4.67 \mathrm{a}$ & $4.50 \mathrm{~b}$ & $56.04 \mathrm{ab} 54.00 \mathrm{c}$ & $7.06 \mathrm{a}$ & $7.06 \mathrm{ab}$ & $56.91 \mathrm{ab}$ & $61.64 \mathrm{a}$ \\
\hline & $\mathrm{P} 3$ & $3.50 \mathrm{c}$ & $3.73 \mathrm{c}$ & $52.50 \mathrm{~b} \quad 55.95 \mathrm{ab}$ & $7.07 \mathrm{a}$ & $7.28 \mathrm{a}$ & $57.30 \mathrm{a}$ & $62.57 \mathrm{a}$ \\
\hline & $\mathrm{P} 4$ & $3.50 \mathrm{c}$ & $3.60 \mathrm{c}$ & $63.00 \mathrm{a} \quad 64.80 \mathrm{a}$ & $7.17 \mathrm{a}$ & $7.23 \mathrm{a}$ & $52.50 \mathrm{~b}$ & $62.43 \mathrm{a}$ \\
\hline & P5 & $2.53 \mathrm{~d}$ & $3.00 \mathrm{~d}$ & $53.13 \mathrm{~b} \quad 63.00 \mathrm{a}$ & $7.04 \mathrm{a}$ & $6.73 \mathrm{~b}$ & $46.06 \mathrm{c}$ & $51.14 \mathrm{~b}$ \\
\hline & P6 & $2.40 \mathrm{~d}$ & $2.47 \mathrm{~d}$ & $57.60 \mathrm{ab} 59.28 \mathrm{ab}$ & $6.96 \mathrm{a}$ & $6.64 \mathrm{~b}$ & $40.45 \mathrm{~d}$ & $42.53 \mathrm{c}$ \\
\hline \multirow[t]{6}{*}{$\mathrm{FB} \geqslant 7$} & $\mathrm{P} 1$ & $5.40 \mathrm{a}$ & $4.90 \mathrm{a}$ & $48.60 \mathrm{ab} 44.10 \mathrm{~b}$ & $6.50 \mathrm{a}$ & $6.33 \mathrm{ab}$ & $36.65 \mathrm{a}$ & $52.88 \mathrm{ab}$ \\
\hline & $\mathrm{P} 2$ & $3.73 \mathrm{~b}$ & $4.83 \mathrm{a}$ & $44.76 \mathrm{bc} 57.96 \mathrm{a}$ & $6.60 \mathrm{a}$ & $6.50 \mathrm{ab}$ & $33.04 \mathrm{~b}$ & $49.83 \mathrm{~b}$ \\
\hline & $\mathrm{P} 3$ & $2.70 \mathrm{c}$ & $3.87 \mathrm{ab}$ & $40.50 \mathrm{c} 58.05 \mathrm{a}$ & $6.63 \mathrm{a}$ & $6.70 \mathrm{a}$ & $34.76 \mathrm{~b}$ & $55.50 \mathrm{a}$ \\
\hline & $\mathrm{P} 4$ & $2.90 \mathrm{c}$ & $2.57 \mathrm{bc}$ & $52.20 \mathrm{a} \quad 46.26 \mathrm{~b}$ & $6.85 \mathrm{a}$ & $6.53 \mathrm{ab}$ & $37.83 \mathrm{a}$ & $43.75 \mathrm{c}$ \\
\hline & P5 & $1.23 \mathrm{~d}$ & $1.80 \mathrm{~cd}$ & $25.83 \mathrm{~d} 37.80 \mathrm{c}$ & $6.55 \mathrm{a}$ & $6.04 \mathrm{bc}$ & $25.69 \mathrm{c}$ & $32.14 \mathrm{~d}$ \\
\hline & P6 & $1.27 \mathrm{~d}$ & $0.60 \mathrm{~d}$ & $30.48 \mathrm{~d} \quad 14.40 \mathrm{~d}$ & $6.07 \mathrm{a}$ & $5.54 \mathrm{c}$ & $26.03 \mathrm{c}$ & $18.56 \mathrm{e}$ \\
\hline
\end{tabular}




\section{Table 4(on next page)}

Regression equations of canopy variables with plant density. 
1 Table 4 Regression equations of canopy variables with plant density.

\begin{tabular}{|c|c|c|c|c|c|}
\hline Layer & Factor & Fitting equation & $\begin{array}{l}\text { Correlation } \\
\text { coefficient }\end{array}$ & P-value & RMSE \\
\hline \multirow[t]{3}{*}{ Upper } & Fraction of light intercepted (\%) & $y=-0.0456 x^{2}+1.6132 x+13.792$ & 0.8602 & 0.05 & 0.66 \\
\hline & Temperature $\left({ }^{\circ} \mathrm{C}\right)$ & $y=-0.2885 x+38.867$ & 0.9951 & 0.00 & 0.13 \\
\hline & Relative humidity(\%) & $\mathrm{y}=0.7742 \mathrm{x}+30.055$ & 0.9757 & 0.00 & 0.77 \\
\hline \multirow[t]{3}{*}{ Middle } & Fraction of light intercepted (\%) & $y=0.67 x+44.774$ & 0.7143 & 0.03 & 2.66 \\
\hline & Temperature $\left({ }^{\circ} \mathrm{C}\right)$ & $y=-0.1663 x+33.555$ & 0.9851 & 0.00 & 0.13 \\
\hline & Relative humidity(\%) & $\mathrm{y}=0.6271 \mathrm{x}+41.711$ & 0.9690 & 0.00 & 0.70 \\
\hline \multirow[t]{3}{*}{ Lower } & Fraction of light intercepted (\%) & $y=-0.1052 x^{2}+4.6195 x+31.291$ & 0.9538 & 0.01 & 1.97 \\
\hline & Temperature $\left({ }^{\circ} \mathrm{C}\right)$ & $y=-0.1684 x+32.22$ & 0.9744 & 0.00 & 0.17 \\
\hline & Relative humidity(\%) & $y=0.6054 x+46.512$ & 0.9671 & 0.00 & 0.70 \\
\hline
\end{tabular}


Figure 1

The planting pattern and drip irrigation pipe layout.

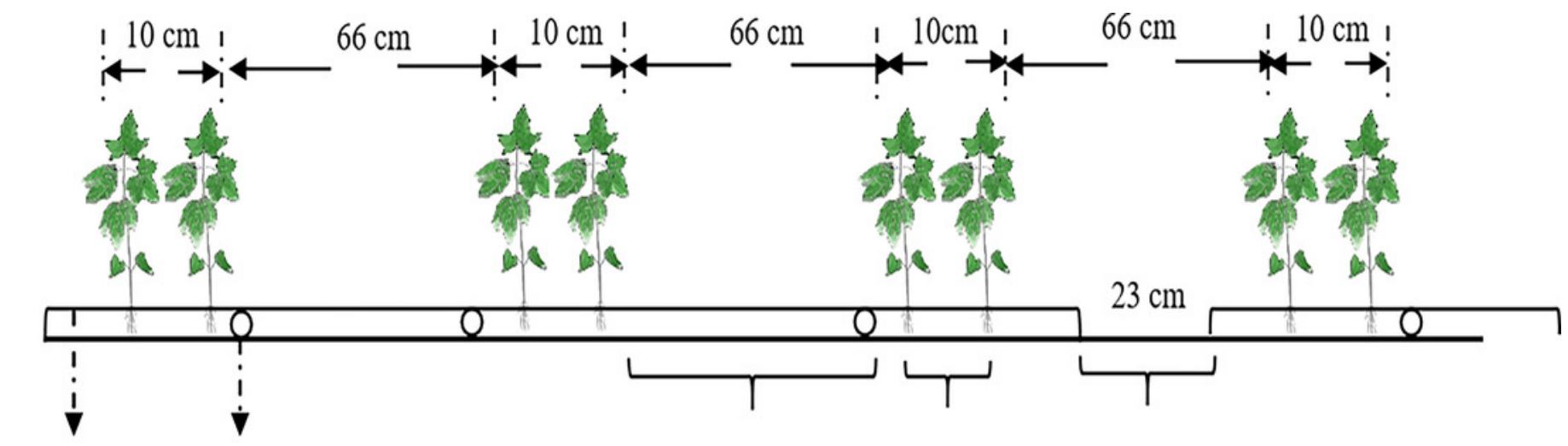

Mulch film Drip pipe $\quad$ Wide row Narrow row Film spacing 
Figure 2

Figure 2 Vertical distribution of cotton canopy layers.

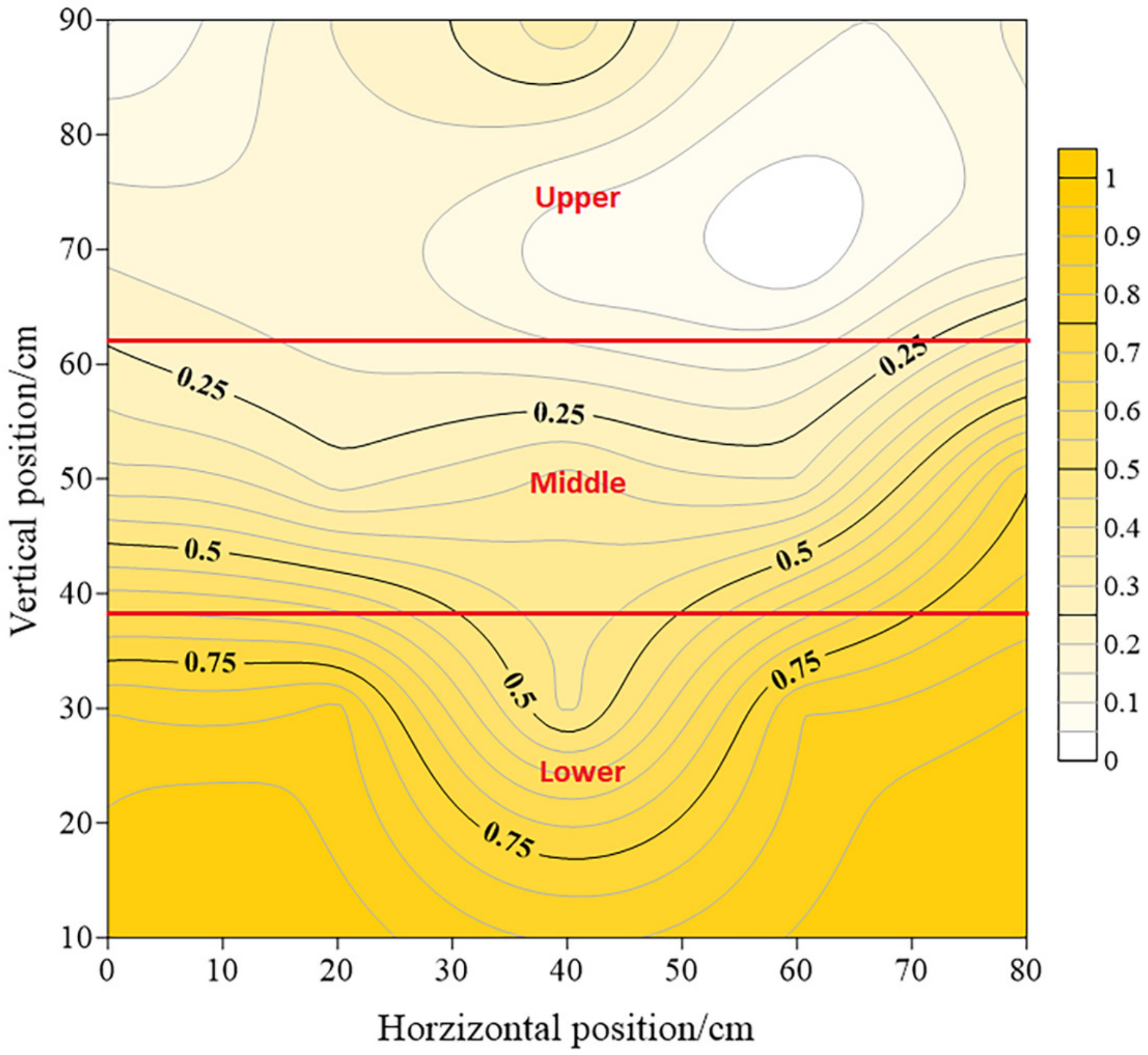


Figure 3

Distribution of canopy FLI within the canopy in response to plant density.

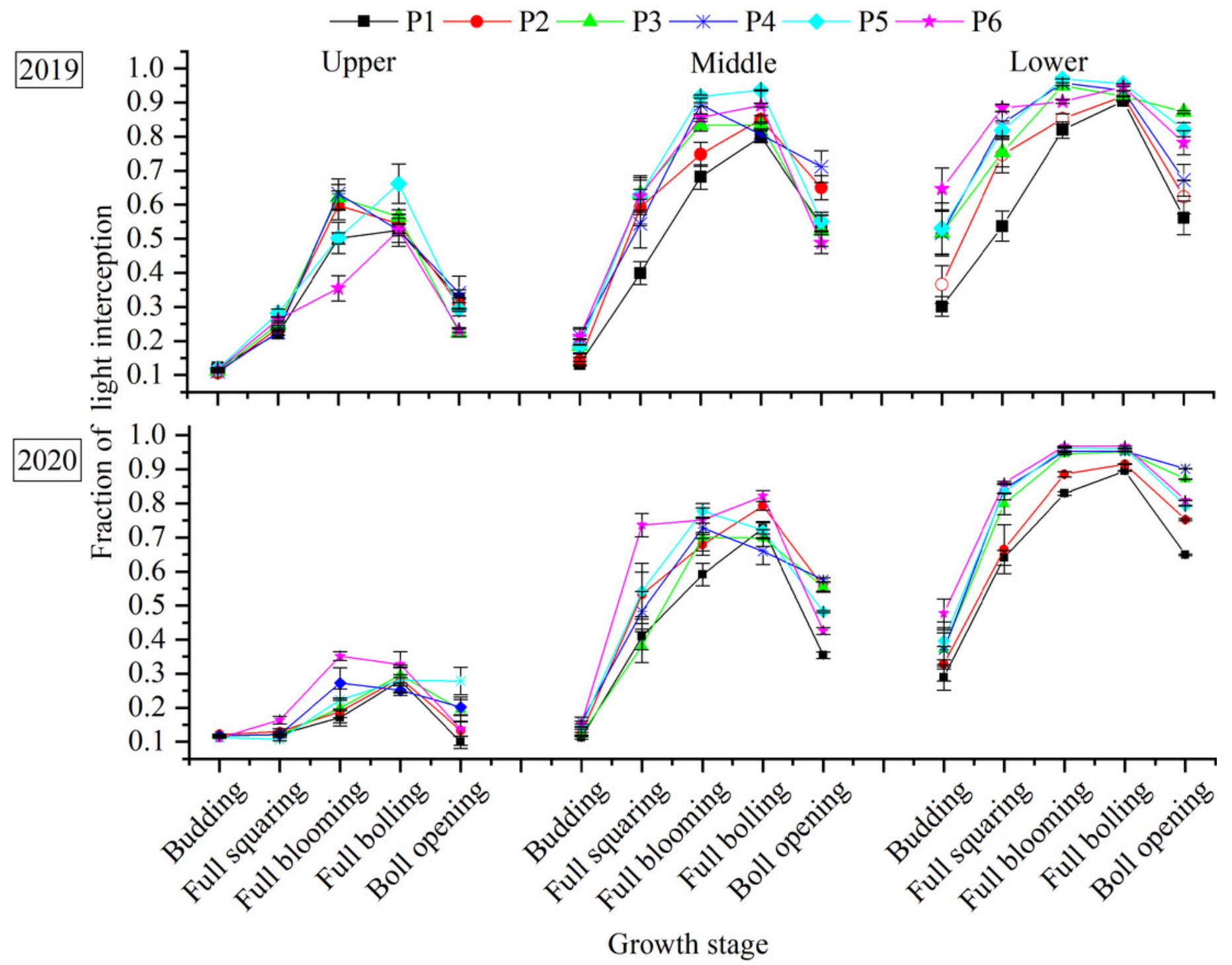


Figure 4

Distribution of air T within the canopy in response to plant density.

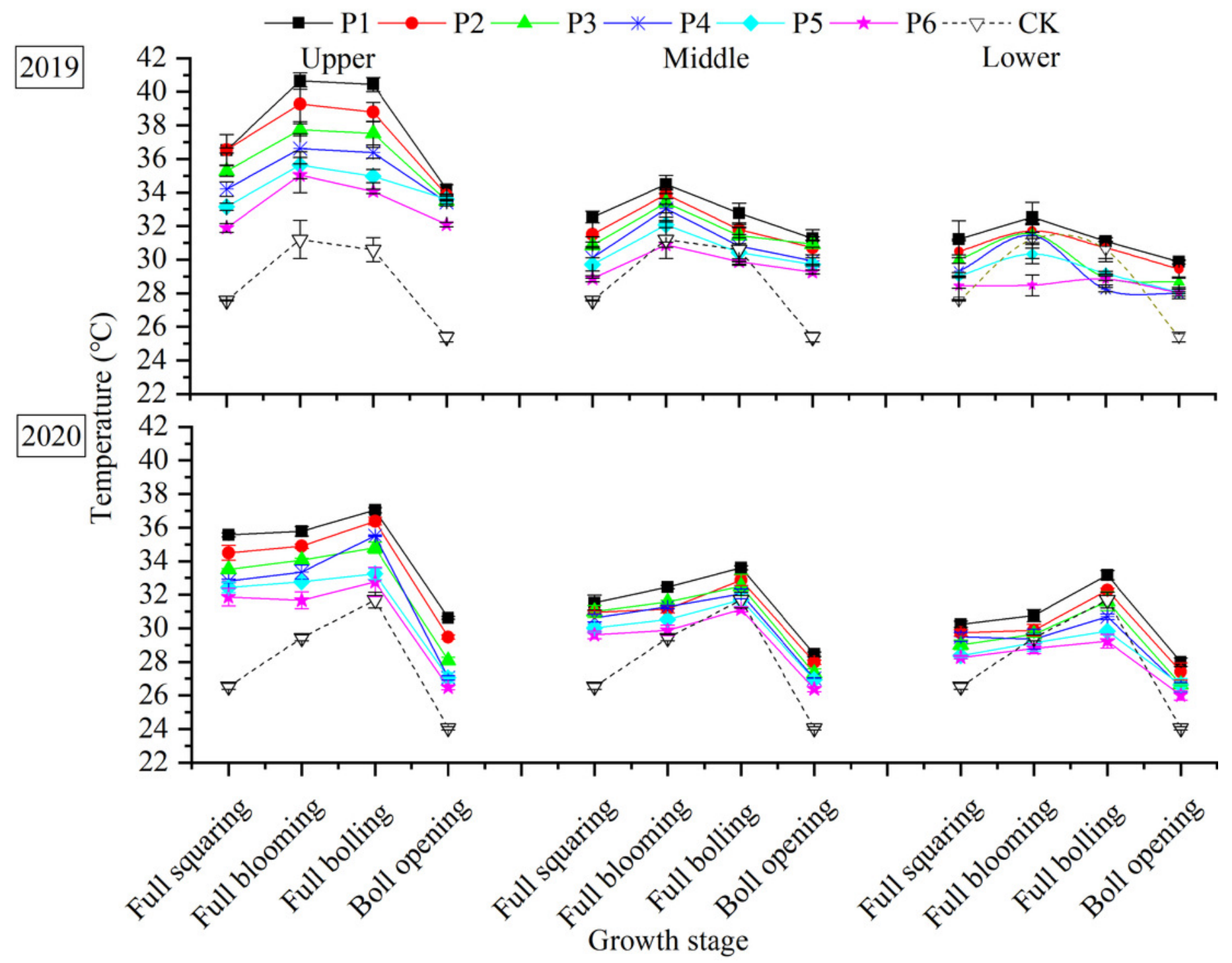


Figure 5

Distribution of RH within the canopy in response to plant density.

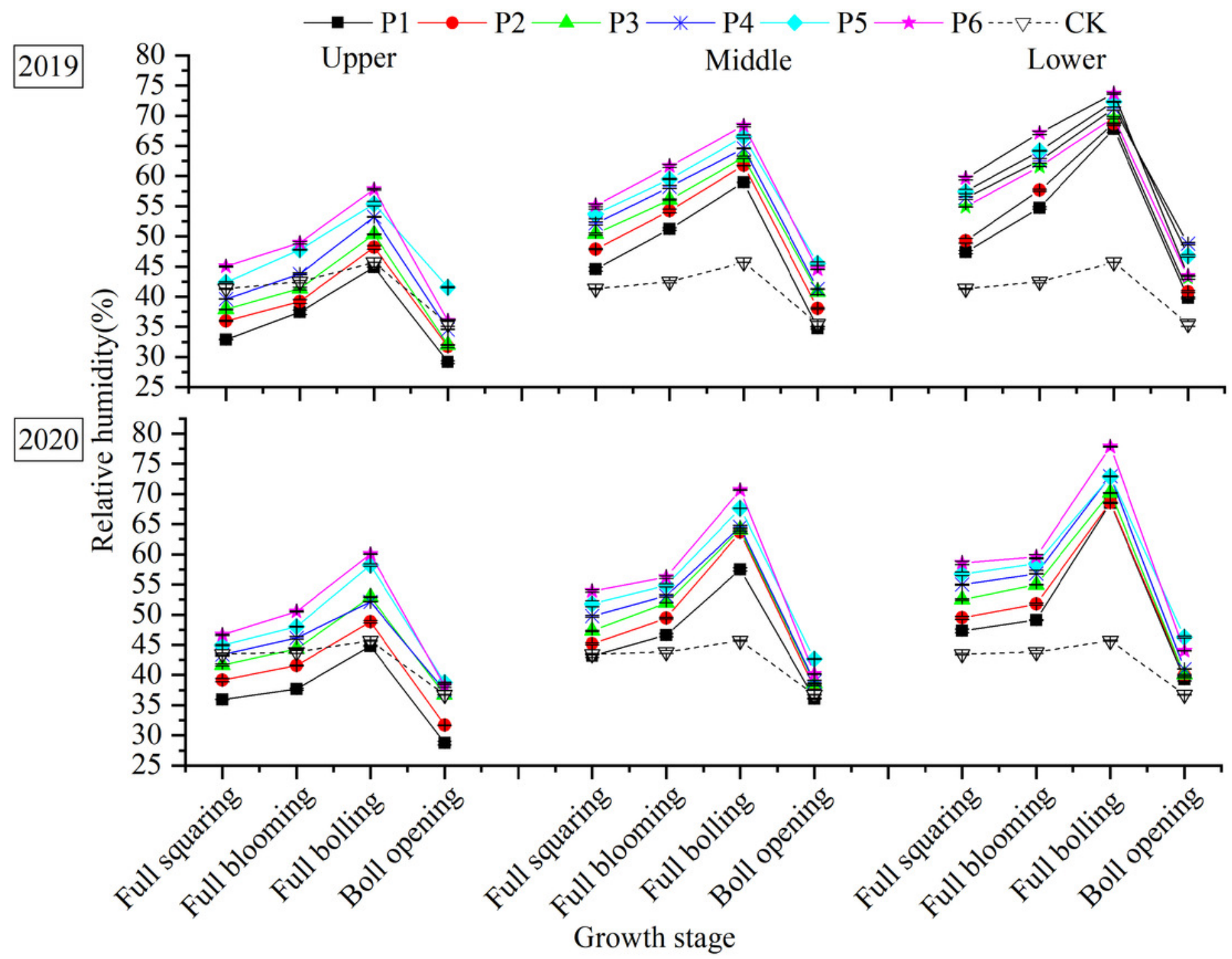


Figure 6

Fits of plant density with canopy FLI, T and RH

- Fraction of light intercepted $\bigcirc$ Temperature $\Delta$ Relative Humidity $—$ Fit curve
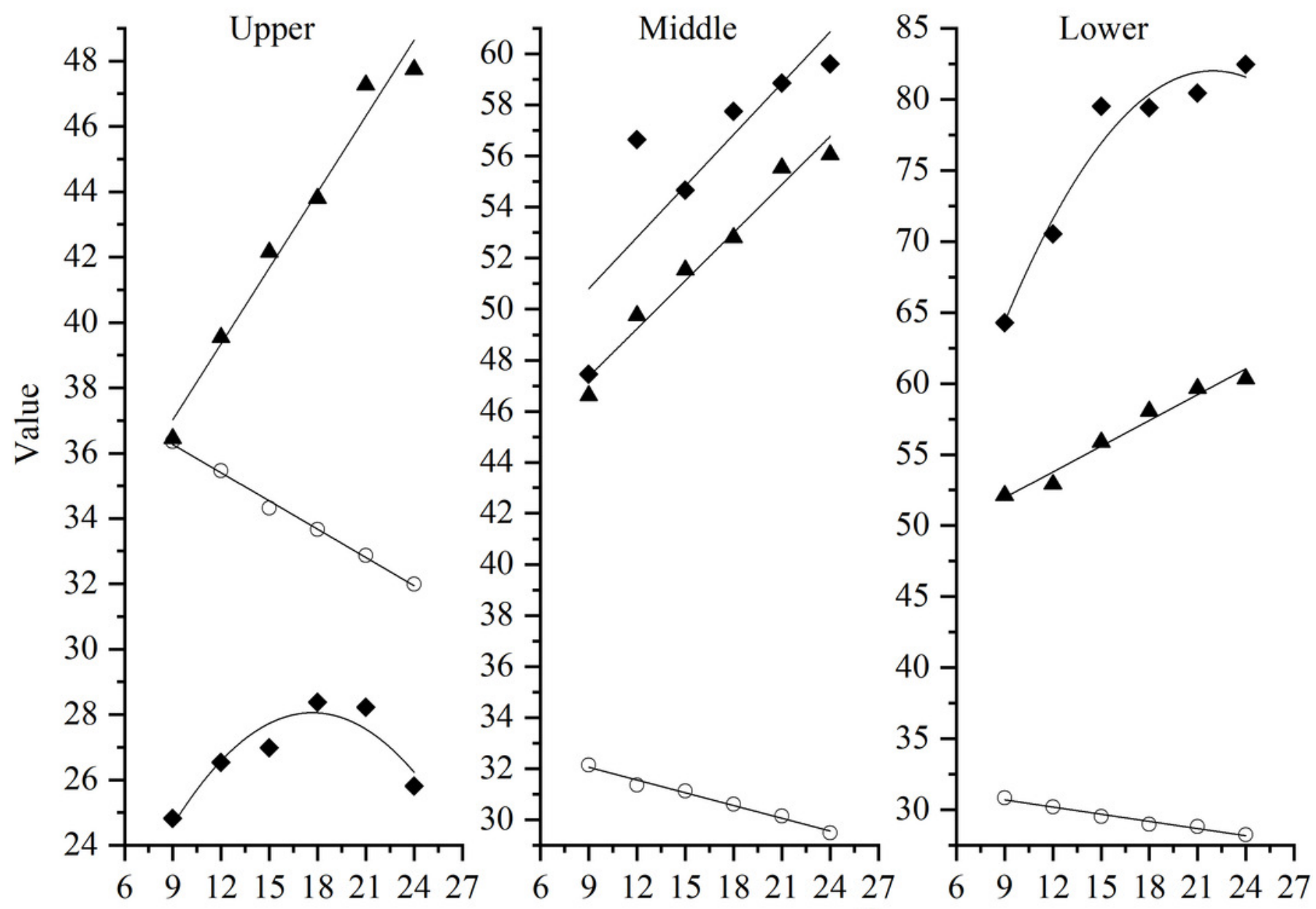

Plant density (plants $\cdot \mathrm{m}^{-2}$ ) 


\section{Figure 7}

Correlations of canopy FLI, T, and RH with BNF, BNA, BW, and BSR.
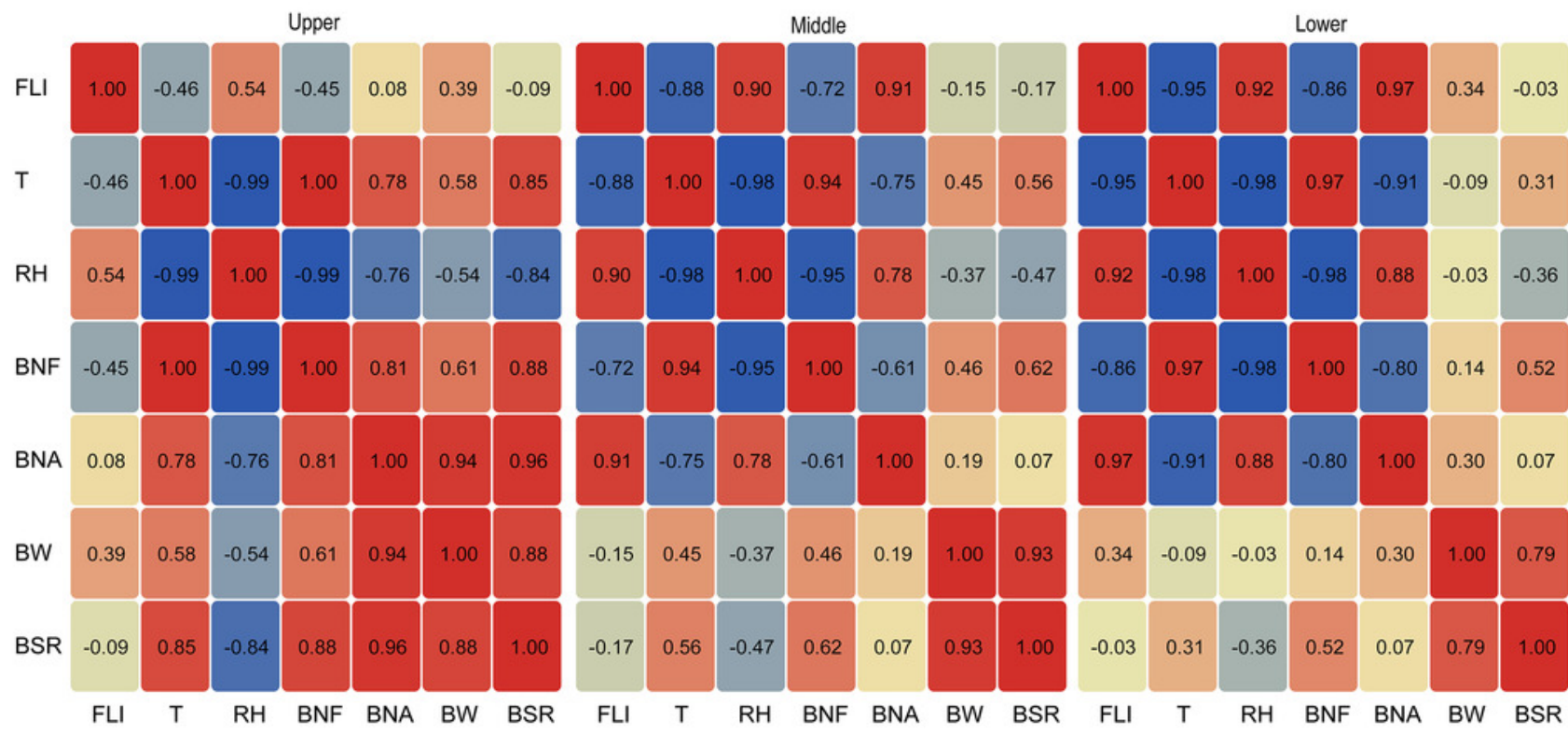

1.00
0.90
-0.60
-0.30
-0.00
-0.30
-0.60
-0.90
-1.00 
Figure 8

Seed cotton yield per unit area in 2019 and 2020.

The different small latter above the columnar represents significant differences at $P<0.05$.
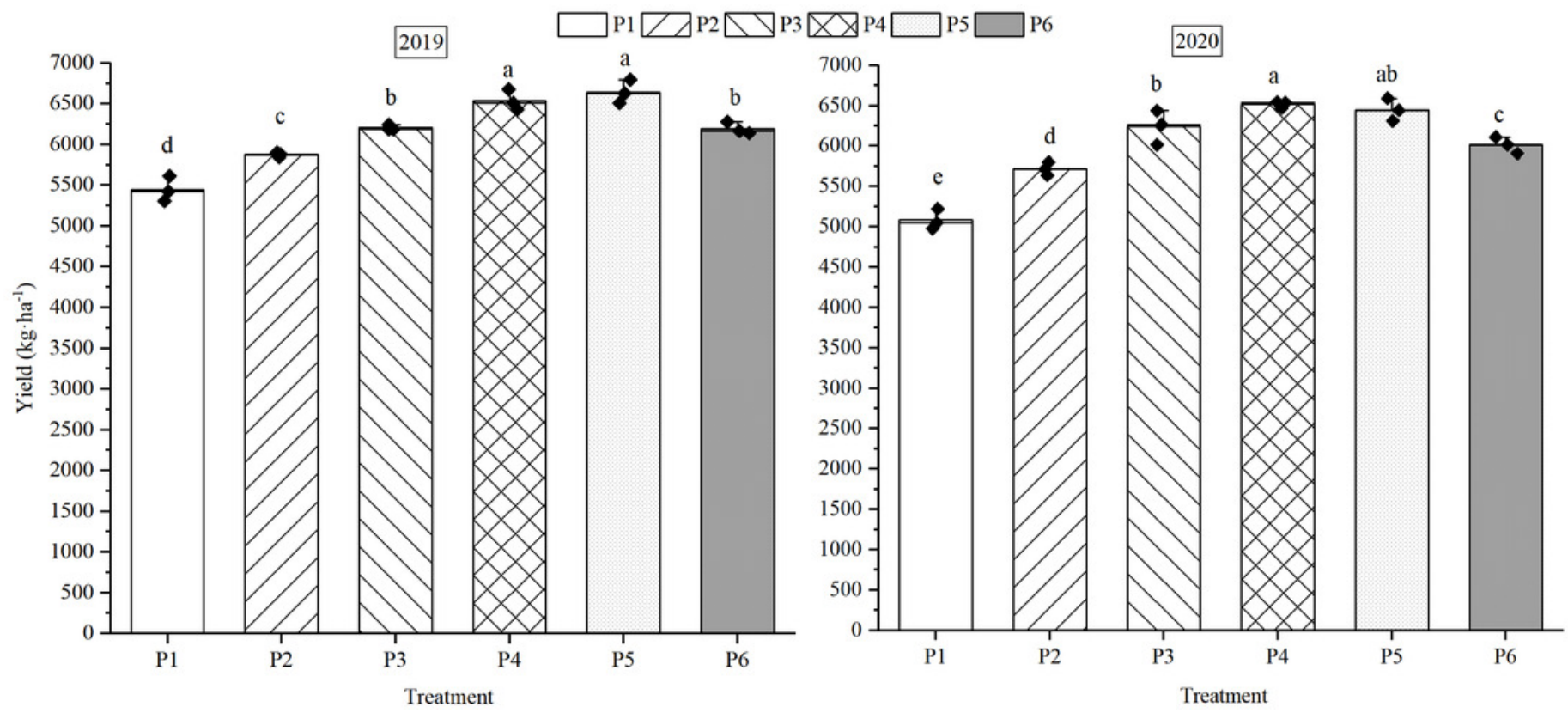
Figure 9

Cotton yield in response to plant density in 2019 and 2020 .

Symbols in each year represent a single harvest seed cotton yield $(n=3)$

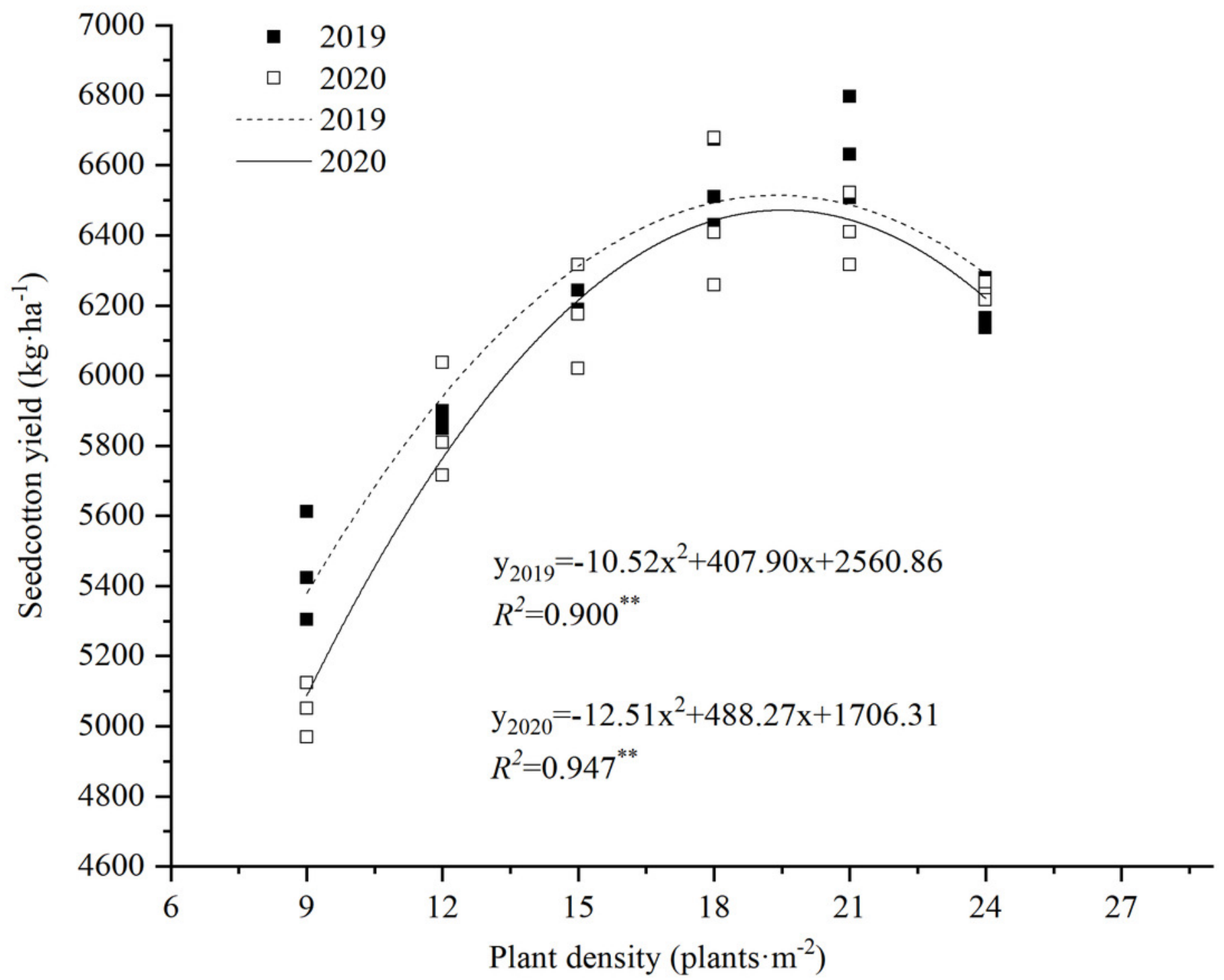

